Katarzyna Wojtanowicz

Uniwersytet Papieski

Jana Pawła II w Krakowie
Kiedy myślimy Rodzina..., red. M. Duda, K. Kutek-Sładek, Kraków 2016, s. 443-456 (Praca Socjalna w Teorii i Działaniu, 2).

\title{
Profilaktyczna praca socjalna wobec kryzysów w rodzinie
}

\section{Preventive social work to the crises in the family}

\begin{abstract}
The contemporary social work sion. In the present article they made is being carried out wielowymiarowo. However she is directed in great measure at action emergency, requiring involving many services, specialists and the institution as well as centres. Social politicians in harmony are raising an alarm for strengthening precautions, as more effective and in consequence also and cheaper in the financial dimenthe presentation of two methods of the preventive social work with the family; of Conference of the Family Group and family mediation, pointing to benefits from applying them.

Keywords: social work, prevention in the social work, social work with the family
\end{abstract}

Współczesna praca socjalna realizowana jest wielowymiarowo. Ukierunkowana jest jednak w znacznej mierze na działania interwencyjne, wymagające zaangażowania wielu służb, specjalistów i instytucji, jak i środków. Działania te, choć są wielokierunkowe, nie przynoszą jednak zadowalających efektów zarówno dla samych realizatorów pracy socjalnej, jak i ich klientów.

Zgodnie z ustawą o pomocy społecznej „praca socjalna to działalność zawodowa mająca na celu pomoc osobom i rodzinom we wzmacnianiu lub odzyskiwaniu zdolności do funkcjonowania w społeczeństwie poprzez pełnienie odpowiednich ról społecznych oraz tworzenie warunków sprzyjających temu celów”'.

1 Ustawa z dnia 12 marca 2004 roku o pomocy społecznej, ze zmianami (Dz. U. z dn. 30.01.2015r., poz. 163), art. 6, p. 12. 
Tak więc już w samej definicji dopatrujemy się akcentu profilaktycznego, a nie tylko interwencyjnego.

Powszechnie wiadomo, potwierdzają to również różnorodne badania naukowe, że zapobieganie szkodliwym zjawiskom społecznym jest: bardziej korzystne zarówno dla jednostek, grup jak i społeczności lokalnych; bardziej skuteczne; bardziej ekonomiczne. Rodzi się zatem pytanie: jak realizować profilaktykę w pracy socjalnej?

Jak pokazuje praktyka, ale również kierunek projektowanych zmian w Ustawie o pomocy społecznej zarówno specjaliści, jak i ustawodawca postulują powrót do większego nacisku na podejmowanie działań profilaktyczne.

\section{Różne spojrzenia na rozumienie i kierunkowanie działań profilaktycznych w pracy socjalnej}

Praktycy, badacze i politycy społeczni ciągle poszukują rozwiązań, które wpłyną na podniesienie efektywności działań, jakie są i będą w przyszłości podejmowane przez instytucje pomocy społecznej, i które ograniczą skalę udzielanej pomocy. Starając się stworzyć nowy model pomocy społecznej w Polsce, $z$ jednej strony zadeklarowano, że ma ona pełnić rolę kompensacyjną wobec innych systemów zabezpieczenia społecznego. W szczególności świadczenia pieniężne mają przybrać charakter uzupełniający w stosunku do systemu ubezpieczeń społecznych i wypełniać luki powstałe na jego obrzeżach. Oznacza to, że zgodnie z ustrojową zasadą subsydiarności pomoc społeczna stanowiłaby ostatnie ogniwo w całym systemie rozwiązań służących budowaniu bezpieczeństwa socjalnego i ładu społecznego. Z drugiej strony, w trakcie projektowania konkretnych rozwiązań prawnych okazało się, że pomoc społeczna zaczyna stanowić najważniejszy lub, można by powiedzieć, najłatwiejszy instrument rozwiązywania wielu kwestii i problemów społecznych. Ta niespójność wizji polskiego systemu pomocy społecznej jest wynikiem braku debaty nad wyborem nadrzędnego modelu polityki społecznej. Nowy system był tworzony w odpowiedzi na zaistniałe problemy społeczne (głównie bezrobocie) i modyfikowany w toku działań doraźnych, zwłaszcza pod presją czynienia oszczędności w wydatkach społecznych. Brak całościowych i spójnych rozwiązań oraz rosnąca skala ubóstwa sprawiły, że pomoc społeczna, która miała być elementem uzupełniającym zabezpieczenia społecznego - stała się jego elementem wiodącym.

Głównymi celami, które stawiamy w profilaktyce społecznej jest realizacja działań w dwóch obszarach: 
- zapobieganie niepożądanym zjawiskom i łagodzenie ich przebiegu,

- eliminowanie bądź ograniczanie przyczyn występowania zaburzeń.

Lesław Pytka definiuje dwa rodzaje profilaktyki: pozytywną i negatywną. Profilaktyka pozytywna ukierunkowana jest na rozwijanie, promowanie, rozpowszechnianie i inicjowanie wszelkich działań wspomagających zachowania akceptowane społecznie w środowisku. Natomiast profilaktyka negatywna według autora jest ukierunkowana na zwalczanie, blokowanie, odstraszanie, napiętnowanie, niedopuszczenie do pojawienia się oraz rozprzestrzeniania sytuacji i zjawisk patologicznych ${ }^{2}$.

Ewa Wysocka za Aleksandrem Kamińskim wskazuje na zakresy działań społecznych, również zdefiniowanych w dwóch wymiarach. W szerokim rozumieniu wskakując na pomoc świadczoną najszerszym grupom społecznym w celu profilaktycznego zapobiegania wszelkim przejawom negatywnych zjawisk społecznych, zaś w wąskim - kompensacyjnym - jako ratownictwo obejmujące ograniczona liczbę osób, m.in. chorych fizycznie i psychicznie, osamotnionych, uzależnionych, upośledzonych. W takim rozumieniu działania profilaktyczne kierowane są do szerszych zbiorowości, a nie do jednostek ${ }^{3}$.

Komitet Rady Europy określił, że „praca socjalna jest specyficzną działalnością zawodową, mającą na celu lepszą adaptację wzajemną osób, rodzin, grup i środowiska społecznego, w jakim żyją, oraz rozwijanie poczucia godności osobistej i odpowiedzialności jednostek na drodze odwoływania się do potencjalnych możliwości poszczególnych osób, do powiązań międzyprofesjonalnych, a także sił i środków społecznych"4. Zgromadzenie Ogólne Międzynarodowej Federacji Pracowników Socjalnych (International Federation of Social Workers), skupiająca zawodowe organizacje pracowników socjalnych z ponad 80 państw, w tym Polski, wypracowało definicję przyjętą w 2001 roku, określającą, że „praca socjalna wspiera zmiany społeczne, rozwiązywanie problemów w stosunkach międzyludzkich oraz wydobywanie z ludzi sił i wolności, aby mogli osiągnąć dobrobyt. Używając teorii zachowań ludzkich i systemów społecznych, praca socjalna oddziałuje tam, gdzie ludzie wchodzą w interakcje ze środowiskiem. Fundamentalne dla pracy socjalnej są zasady praw człowieka i sprawiedliwości społecznej"5.

\footnotetext{
2 L. Pytka, Pedagogika resocjalizacyjna, Warszawa 2001, s. 218.

3 E. Wysocka, Opieka czy pomoc oraz ich wymiary i wyznaczniki z perspektywy psychologicznej, [w:] Działanie społeczne w pracy socjalnej na progu XXI wieku, red. E. Kantowicz, A. Olubiński, Toruń 2004, s. 304-305.

4 B. Szatur-Jaworska, Teoretyczne podstawy pracy socjalnej, [w:] Pedagogika społecz$n a-c z l o w i e k$ zmieniającym się świecie, red. T. Pilch, I. Lepalczyk, Warszawa 2003.

5 D. Wolska-Prylińska, Projekt socjalny w kształceniu i działaniu społecznym, Katowice 2010 , s. 22.
} 
Ewa Marynowicz-Hetka (za Robertem Castelem) wskazuje następujące funkcje pracy socjalnej6:

- ochronna, która stymuluje pracę socjalną jako strażnika i stymulatora zmian w życiu społecznym oraz dystrybutora dóbr. Pracownik socjalny jest tu traktowany jako zaradzający problemami społecznymi,

- kontestująca, w której pracownik socjalny skupia swe działanie na uświadamianiu mechanizmów społecznych i przedstawia się jako rzecznik osób wyłączonych z życia społecznego. Pracownik socjalny jest tu traktowany bardziej jako działacz społeczny niż pracownik,

- mediacyjna, którą przeciwstawia się zarządzaniu problemami społecznymi. W tym ujęciu pracownik socjalny podejmuje wspólnie z klientem opracowanie kontraktu socjalnego. Pracownik socjalny stawia się w roli towarzysza i osoby wspierającej jednocześnie.

Zgromadzenie Ogólne Międzynarodowej Federacji Pracowników Socjalnych IFSW w 2014 roku określiło, że praca socjalna jest zawodem bazującym na praktyce i jest dyscypliną akademicką. Celem jej działań są zmiany społeczne i rozwój społeczny, integracja społeczna oraz upodmiotowienie i wyzwolenie ludzi. Kluczowe dla pracy socjalnej są zasady sprawiedliwości społecznej, praw człowieka, odpowiedzialności publicznej oraz szacunku dla różnorodności. Praca socjalna - na podstawie swej teorii, nauk społecznych i humanistycznych oraz wiedzy lokalnej - angażuje ludzi i struktury instytucjonalne w odpowiedzi na wyzwania życiowe i w celu zwiększania ich dobrostanu. Definicja ta może być rozwijana na potrzeby krajowe i/lub regionalne.

Tak więc pracę socjalną cechuje dynamiczny proces, podlegający ciągłej analizie, zorientowany na profilaktykę i przybliżanie problemów społecznych oraz działanie w kierunku wywołania zmiany.

\section{Działania profilaktyczne w pracy socjalnej}

Współczesna polityka społeczna, aby osiągnąć zrównoważony poziom rozwoju społecznego, szczególnie w zakresie pomocy społecznej, to jest w stosunku do osób słabszych, niepełnosprawnych, wymagających wsparcia i pomocy, musi zastosować mechanizmy polityki aktywnej, tj. takiej, która angażuje wszystkie zasoby instytucjonalne, organizacyjne, materialne, a przed wszystkim osobowe. W tym wymiarze bardzo ważną rolę odgrywa kapitał społeczny, który z jednej strony może realizować szereg działań środowiskowych, z drugiej zaś samorealizować swój proces wprowadzania zmiany i rozwoju.

6 E. Marynowicz-Hetka, Pedagogika społeczna, Warszawa 2005, s. 357-358. 


\section{Konferencja Grupy Rodzinnej- narzędzie profilaktyki na rzecz samorealizacji funkcji rodziny}

Konferencja Grupy Rodzinnej (KGR) to metoda pracy z rodziną, z dużym powodzeniem stosowana na świecie od kilkunastu lat. W Polsce również odnotowano kilka projektów jej implementacji, jednak na szerszą skalę się to nie udało.

Założeniem tej metody jest, że każda rodzina jako niepowtarzalna, jedyna w swoim rodzaju, posiada „zdrowe” zasoby, aby pokonać większość trudności, jeśli nie wszystkie, które się w niej pojawią. Zasoby rodziny są punktem wyjścia do tego, aby przekazać rodzinie odpowiedzialność za rozwiązanie problemów w swoim gronie. To właśnie członkowie rodziny, po uzyskaniu niezbędnych informacji, stymulacji do mobilizacji swoich potencjałów, zasobów i łączących ich więzi, mogą odmienić losy swojej rodziny ${ }^{7}$.

Konferencja Grupy Rodzinnej jest spotkaniem, w którym uczestniczy jak największa liczba członków rodziny. Rodzina spotyka się, by we własnym gronie podjąć próbę rozwiązania problemu, jaki się w niej pojawił. Głównym celem konferencji jest stworzenie przez rodzinę planu, który ma doprowadzić do udzielenia wsparcia w rozwiązaniu problemu.

W spotkaniu rodzinnym KGR udział biorą:

- dziecko/dzieci,

- rodzice lub opiekunowie,

- dalsza rodzina (ciocie, wujkowie, rodzice chrzestni),

- przyjaciele rodziny,

- osoby wspierające (szczególnie dla dzieci lub ofiary przemocy),

- specjaliści z zakresu problemu/problemów występujących w rodzinie,

- osoba zgłaszająca (np. pracownik socjalny, kurator),

- koordynator.

Przygotowaniem konferencji zajmuje się rodzina przy wsparciu koordynatora. Jest to kluczowa osoba, gdyż od jej kompetencji zależy powodzenie całego procesu. Koordynator jest osobą neutralną, najlepiej niezwiązaną zawodowo i osobiście z rodziną - tzn. koordynator pracujący w systemie pomocy społecznej nie może na co dzień pracować bezpośrednio z rodziną, której spotkanie podejmuje się koordynować. Poczucie neutralności koordynatora powinno także dotyczyć jego zaangażowania w proces rozwiązywania problemów przez rodzinę $e^{8}$.

7 E. Dybowska, K. Wojtanowicz, System wspierania i formy pracy z rodzina, Kraków 2013, s. 35 .

8 J. Przeperski, Praca z rodzina z zastosowaniem metody Konferencja Grupy Rodzinnej, „es.O.es” (2006) nr 2, s. 1-2. 
Etapy spotkania KGR:

- dzielenie się informacjami

$\mathrm{Na}$ wstępie spotkania wszystkich zgromadzonych wita koordynator. Następnie osoba zgłaszająca, np. pracownik socjalny, przedstawia sytuację, w jakiej znalazła się rodzina. Odpowiada na pytania zadawane przez członków rodziny. Prezentuje również możliwości pomocy, jakie oferuje rodzinie system pomocy. Następnie głos zabierają specjaliści (jeżeli wystąpiła potrzeba ich zaproszenia), którzy mogą udzielić fachowych informacji dotyczących problemu występującego w rodzinie.

- prywatny czas dla rodziny

W tej części spotkania pomieszczenie opuszczają zaproszeni specjaliści, osoba zgłaszająca i koordynator, a rodzina pozostaje sama oraz poszukuje optymalnych rozwiązań i sporządza plan pomocy rodzinie na piśmie.

- zaakceptowanie planu stworzonego przez rodzinę

Pracownik socjalny zapoznaje się z planem pomocy wypracowanym przez rodzinę. Następnie podejmuje decyzję, czy ta propozycję zaspokaja potrzeby i problemy rodziny, głównie pod względem bezpieczeństwa dla dziecka i rodziny, oraz ustala wspólnie z rodziną sposoby wprowadzenia go w życie.

- realizacja planu

Koordynator przekazuje każdemu uczestnikowi konferencji kopię sporządzonego planu. Przyjęcie planu przez rodzinę jest formą kontraktu, który podpisują wszyscy uczestnicy spotkania. Następnie rodzina przystępuje do jego realizacji oraz wybiera spośród siebie osobę ds. kontaktów z pracownikiem socjalnym.

- kontrola realizacji planu

Zakończenie konferencji nie jest jednoznaczne z zakończeniem pracy z rodziną. Na tym etapie koordynator kończy pracę, a kontrola realizacji planu powraca do osoby prowadzącej dany przypadek przed zorganizowaniem KGR, tj. najczęściej pracownika socjalnego, który zgodnie z Ustawą o pomocy społecznej i tak jest zobowiązany pracować z daną rodziną oraz, co najważniejsze, do samej rodziny.

Przekazanie rodzinie funkcji kontrolnej jest jedną z fundamentalnych zasad metody. Rodzina w ujęciu KGR jest traktowana jako ekspert, który jest w stanie najlepiej ocenić możliwości rodziny, jej dynamikę oraz sposoby podejmowania decyzji. Nikt spoza rodziny nie zna historii danej rodziny lepiej niż ona sama.

W jakich przypadkach możemy zastosować metodę KGR?

Metoda znajduje wszechstronne zastosowanie w sytuacjach kryzysowych występujących w rodzinie. Szczególnie w przypadkach: 
- przemocy psychicznej, fizycznej lub seksualnej w rodzinie,

- trudności wychowawczych w rodzinie,

- trudności w nauce i zaburzeń zachowania u dzieci,

- umieszczenia dzieci w placówkach opiekuńczo-wychowawczych lub rodzinach zastępczych, szczególnie w zakresie nawiązania i podtrzymania relacji z rodziną, a także powrotu do rodziny,

- usamodzielniania z placówek opiekuńczo-wychowawczych lub rodzin zastępczych,

- niepełnosprawności lub długotrwałej choroby,

- opieki nad osobami starszymi,

- uzależnień występujących w rodzinie,

- eurosieroctwa9 .

Właściwie trudno znaleźć przypadek, w którym nie można zastosować tej metody. Jej zastosowanie przynosi bardzo wymierne korzyści i z pewnością można ją zaliczyć do metod o charakterze profilaktycznym wobec rozwiązywania kryzysów w rodzinie. Do najważniejszych korzyści z zastosowania metody możemy zaliczyć:

- zaangażowanie całej rodziny w rozwiązanie problemów,

- przekazanie rodzinie odpowiedzialności za swoje funkcjonowanie, rozwój i rozwiązanie sytuacji trudnych,

- doświadczenie przez rodzinę, że posiada moc sprawstwa i decydowania w swoich sprawach,

- zaangażowanie środowiska lokalnego w pomoc rodzinie,

- osłabienie syndromu wyuczonej bezradności i bierności w rodzinie,

- wzmocnienie funkcjonowania rodziny,

- przeniesienie ciężaru odpowiedzialności za rodzinę z systemu pomocowego i osób w nim pracujących na rodzinę ${ }^{10}$.

Zastosowanie metody KGR w pracy z rodziną przeżywającą trudności w realizacji swoich funkcji, samodzielnym zaspokajaniu swoich potrzeb, jest bez wątpienia działaniem profilaktycznym, skierowanym na wzmocnienie i budowanie potencjału rodziny. To właśnie przy takim wsparciu rodzina jest w stanie samodzielnie przezwyciężać takie sytuacje, ze zbudowaniem silnego potencjału na przyszłość. Potwierdzają to nieliczne, lecz bardzo pozytywnie efektywne przypadki zastosowania tej metody w Polsce.

9 K. Mimiec, J. Przeperski, Praca z rodzina dziecka niepetnosprawnego metodą Konferencji Grupy Rodzinnej, „es.O.es” (2007) nr 1, s. 13.

10 E. Dybowska, K. Wojtanowicz, System wspierania..., dz. cyt., s. 37-38. 


\section{Mediacja rodzinna - narzędzie profilakłyki na rzecz rozwiąywania konfliktów w rodzinie}

Coraz częściej wybieraną formą rozwiązywania konfliktów - także w pracy socjalnej - staje się mediacja, która w dwustronny dialog wprowadza osobę trzecią - mediatora, osobę neutralną, bezstronną, a co najważniejsze - niepodejmującą rozstrzygających decyzji. Mediacja jest rozmową na temat możliwych rozwiązań zaistniałego konfliktu w atmosferze wzajemnego poszanowania oraz zrozumienia potrzeb i interesów obydwu stron. Mediator pomaga spierającym się stronom rozważyć wszystkie możliwe rozwiązania, negocjować je w celu osiągnięcia dobrowolnego i obustronnie satysfakcjonującego porozumienia. Jest to postępowanie nieformalne, gdzie mediator nie jest ani sędzią, ani arbitrem. Oprócz osoby mediatora - w naszym przypadku pracownika socjalnego - równie ważne są zasady, na których opiera się cały proces mediacyjny. Są to:

- dobrowolność - do mediacji strony przystępują całkowicie dobrowolnie. Całkowita dobrowolność udziału, wyboru kwestii, które strony podejmą się omawiać, oraz rozwiązań, które uzgodnią, wpływa na zwiększenie ich odpowiedzialności za proces mediacji oraz na wywiązanie się z podjętych decyzji,

- bezstronność mediatora - mediator nie opowiada się po żadnej ze stron, w równy sposób angażuje się w pomoc obu stronom konfliktu. Nie ocenia ani stron, ani ich zachowań. Nie wskazuje też winnego,

- neutralność - mediator nie podpowiada ani nie narzuca żadnych rozwiązań. Akceptuje wszystkie rozwiązania, które strony wypracują i postanowią podjąć decyzję o ich wprowadzeniu w życie. Rolą mediatora jest tylko pomóc w rozwiązaniu konfliktu, a nie doradzać i wskazywać „dobre” rozwiązania,

- samodzielność w podejmowaniu decyzji - mediator nie podejmuje za strony konfliktu żadnych decyzji, a jedynie zachęca do przejęcia sprawy w swoje ręce. Tylko strony najlepiej wiedzą, co jest dobre dla nich i rodziny. Mediator ma tylko pomóc w uświadomieniu tego,

- poufność - mediacja jest procesem całkowicie poufnym. Cały jej przebieg oraz treść rozmów nie mogą zostać nikomu ujawnione ${ }^{11}$.

Zadaniem mediatora jest dbałość o to, by wszystkie decyzje podejmowane w toku procesu były oparte na zgodzie samych zainteresowanych oraz ich świadomości co do dostępnych możliwości postępowania wobec problemu, jak również zapewnienie, by każda ze stron była traktowana z szacunkiem oraz

11 Mediacje rodzinne w praktyce. Poradnik, Kraków 2008, s. 7-8. 
życzliwością i otrzymywała równoważne wsparcie proceduralne. Mediator poprzez zarządzanie komunikacją, proponowanie i pilnowanie przestrzegania reguł proceduralnych, dbałość o porządek omawianych zagadnień tworzy warunki, w których strony będą mogły przyjrzeć się swojej sytuacji i potrzebom, rozważyć dostępne alternatywy i, przy wykorzystaniu wszelkich informacji potrzebnych do podjęcia decyzji, dokonać ważnych dla siebie wyborów ${ }^{12}$.

\section{Ełapy mediacji}

Mediacja jest procesem nieformalnym, ale zorganizowanym. Przedstawione przez Christofera Moore’a etapy procesu mediacji wraz z działaniami mediatora sprowadzają jej istotę do skupienia stron konfliktu na wzajemnym wysłuchaniu swoich stanowisk oraz wspólnym zdefiniowaniu listy problemów, co ma spowodować przekierowanie stron od przeszłości, związanej z postrzeganiem i odczuwaniem sytuacji konfliktu, do przyszłości i skupienie się na poszukiwaniu rozwiązań na konkretnie zdefiniowane kwestie. Następnie, co wszyscy praktycy wykorzystujący tą metodę podkreślają, następuje najważniejszy etap w drodze do porozumienia: moment odsunięcia problemów i stanowisk na drugi plan i skupienie się stron na wzajemnym „wglądzie w siebie”. Mediator na tym etapie „wstrzymuje” strony konflikty w naturalnym, często dotychczas przez nich stosowanym schemacie: problem - rozwiązanie, które nie przynosiło dotychczas efektów. Mediator w tym „zatrzymaniu” prowadzi strony do zastanowienia się, co jest dla nich najważniejsze i dlaczego to jest dla nich ważne. Dopiero po wzajemnym ujawnieniu i zrozumieniu swoich potrzeb, interesów, które przyświecają stronom, mediator kontynuuje proces. Na tym etapie strony poszukują rozwiązań i rozpoczyna się końcowy etap negocjacji rozwiązań.

W samym procesie mediacji nie należy zapominać o osobie mediatora, którym w naszych rozważaniach jest pracownik socjalny. Kodeks Etyki Mediatora domaga się od kandydata na mediatora, by posiadał kwalifikacje etyczno-moralne, niezbędne do realizowania tej misji. I tak wymienia:

- uczciwość i bycie godnym zaufania (regularne ocenianie samego siebie, przyjmowanie ocen od innych),

- skupienie, umiejętność koncentrowania się,

- łatwość nawiązywania kontaktu z innymi, otwartość,

- umiejętność aktywnego słuchania,

12 A. Gójska, V. Huryn, Mediacja w rozwiązywaniu konfliktów rodzinnych, Warszawa 2007, s. 25. 
- umiejętność okazywania szacunku innym,

- dokładność i odpowiedzialność,

- życzliwość,

- cierpliwość (unikanie zawarcia pochopnej ugody),

- tolerancja,

- działanie bez przemocy ${ }^{13}$.

Jak podaje Hanna Przybyła-Basista, mediator nie występuje ani w roli terapeuty, ani sędziego czy prawnika. Zachowując neutralną postawę, działa jako doświadczony negocjator, umożliwiający dwóm stronom rozpoznawanie realiów i odnajdywanie rozwiązań kompromisowych ${ }^{14}$.

\section{Techniki komunikacji stosowane w mediacji}

Umiejętność skutecznej komunikacji należy do najbardziej pożądanych umiejętności zawodowych osób pracujących z drugim człowiekiem, szczególnie tych, które w wyniku swoich oddziaływań mają wpływać na zmianę postaw swoich klientów. Wzajemne zrozumienie, wspólne wypracowanie porozumienia $\mathrm{w}$ drodze podjęcia dialogu wspiera stosowanie adekwatnych narzędzi komunikacji. Ważnym aspektem jest również uczenie osób, z którymi podejmujemy pracę, prawidłowych zasad komunikowania. Pierwszym z warunków poprawnej komunikacji jest aktywne słuchanie, które polega na rozpoznawaniu wszystkich sygnałów, które wysyła druga osoba. Na aktywne słuchanie składa się motywacja do wysłuchania drugiej strony, cierpliwość, uważność, koncentracja. Prowadzi to do zrozumienia wypowiedzi rozmówcy. Aktywne słuchanie oraz komunikowanie się ułatwia zastosowanie technik komunikacji. Do najbardziej pożądanych w procesie komunikacji należą:

- odzwierciedlanie (uczuć) - to technika polegająca na dopasowaniu się wewnętrznego i zewnętrznego świata rozmówcy. Nazywanie uczuć buduje poczucie zrozumienia i zaufanie,

- parafraza - zapobiega postawie „wiem dobrze, co chcesz powiedzieć”, uniemożliwiającej prawdziwy dialog poprzez reagowanie na własne domysły, a nie na to, co chce nam powiedzieć rozmówca. Polega na powtó-

13 Kodeks Etyki Mediatora, mediator.org.pl http://mediator.org.pl/Kodeks_Etyki_Mediatora/86/ (2.10.2013).

14 H. Przybyła, Mediacja małżenska w sprawach rozwodowych, [w:] Wybrane metody diagnostyki i interwencji psychologicznej w sadowych sprawach rodzinnych, red. J. M. Stanik, Katowice 1994, s. 87. 
rzeniu własnymi słowami wypowiedzi rozmówcy w celu upewnienia się, że dobrze zrozumieliśmy. Nie jest interpretacją wypowiedzi ani oceną,

- podsumowanie, wyjaśnienie - służy konkretyzowaniu i precyzowaniu ważnych kwestii,

- zadawanie pytań - umiejętność zadawania trafnych pytań, szczególnie otwartych, może znacznie rozwijać rozmowę, wspierać wypowiedzi rozmówców oraz wzbogacać cały proces dialogu,

- dowartościowanie - to pokazanie rozmówcy, że jest ważny, że doceniane są jego wysiłki i podejmowane działania,

- udzielanie informacji zwrotnych - to odpowiedź, jak reagujemy na zachowania i wypowiedzi drugiej strony. Jest źródłem wiedzy o wynikach działania, pozwala na konfrontację i ewentualną zmianę postępowania, pełni funkcję informacyjną i korygującą.

Bardzo istotnym czynnikiem w pozytywnej komunikacji jest również znajomość barier w porozumiewaniu się. Należą do nich: ocenianie, krytykowanie, obrażanie, orzekanie, ale również decydowanie za innych i uciekanie od cudzych problemów. Skutecznej komunikacji można się nauczyć. Należy jednak pamiętać także o tym, że ciągłe mówienie niekoniecznie oznacza komunikację $e^{15}$.

\section{Korzyści dla stron z uczestnictwa w mediacji}

Zadaniem mediatora jest zatem dbałość o to, by wszystkie decyzje podejmowane w toku procesu były oparte na zgodzie samych zainteresowanych oraz ich świadomości co do dostępnych możliwości postępowania wobec problemu, oraz zapewnienie, by każda ze stron była traktowana z szacunkiem i życzliwością oraz otrzymywała równoważne wsparcie proceduralne. Mediator poprzez zarządzanie komunikacją, proponowanie i pilnowanie przestrzegania reguł proceduralnych, dbałość o porządek omawianych zagadnień tworzy warunki, w których strony będą mogły przyjrzeć się swojej sytuacji i potrzebom, rozważyć dostępne alternatywy i, przy wykorzystaniu wszelkich informacji potrzebnych do podjęcia decyzji, dokonać ważnych dla siebie wyborów ${ }^{16}$. Skuteczność mediacji jest oceniana według różnych badań na pozio-

15 Szerzej: S. Morreale, B. Spitzberg, K. Barge, Komunikacja międzyludźmi. Motywacja, wiedza i umiejętności, Warszawa 2012. Także: Z. Nęcki, Komunikacja międzyludzka, Kraków 2000. s. 25 .

16 A. Gójska, V. Huryn, Mediacja w rozwiązywaniu konfliktów rodzinnych, dz. cyt., 
mie 50-80 proc. Najczęściej wskazywanymi korzyściami dla stron uczestniczących w mediacji są między innymi:

- poczucie własnej siły i możliwości poradzenia sobie z własnymi problemami,

- stworzenie możliwości wzajemnego wysłuchania, ujawnienia i zrozumienia potrzeb,

- wypracowanie rozwiązań odpowiadających na potrzeby własne i partnera,

- szczegółowe doprecyzowanie rozwiązań, które określają zobowiązania obu stron,

- większa gotowość i zaangażowanie w realizację wypracowanych rozwiązań,

- udział wspierającego i nieoceniającego mediatora,

- uzyskanie porozumienia szybko, tanio i w sposób bardzo dostępny.

Możliwość dobrowolnego udziału w procesie mediacji, poczucie wpływu na przebieg wydarzeń i podjęte rozwiązania problemów niewątpliwie przekładają się na zaangażowanie stron $\mathrm{w}$ ich realizację. W mediacji strony do końca mają wpływ na ostateczne rozstrzygnięcia, które zatwierdzają własnoręcznym podpisem w porozumieniu, ugodzie mediacyjnej. Taki tok postępowania na drodze do porozumienia $\mathrm{w}$ porównaniu $\mathrm{z}$ innymi metodami, $\mathrm{w}$ tym procesem sądowym, wspomaga proces przejmowania odpowiedzialności za własne postępowanie, a także za realizację podjętych zobowiązań.

\section{Zastosowanie mediacji}

Mediacja ma szerokie zastosowanie. Właściwie można ją zastosować w każdej sytuacji konfliktu, trudności w porozumieniu lub w potrzebie dokonania ustaleń, wprowadzenia nowych rozwiązań. Najpowszechniejsze wykorzystanie mediacji:

- sprawy rodzinne

a. konflikty małżeńskie (o ile nie są wskazaniem do terapii),

b. spory wynikające z gospodarowania współwłasnością (np. sprawy spadkowe),

c. konflikty między rodzicami i dziećmi (także dorosłymi dziećmi),

d. pomoc w uzgodnieniu zasad opieki nad członkami rodziny chorymi, niepełnosprawnymi lub w podeszłym wieku.

- sprawy rozwodowe

a. sposób rozstania, rodzaj pozwu z orzekaniem lub bez orzekania o winie,

b. władza rodzicielska i miejsce zamieszkania dziecka,

c. kontakty dziecka z rodzicem, który nie będzie sprawował bezpośredniej opieki nad nim, 
d. sposób korzystania ze wspólnego mieszkania po rozwodzie,

e. ustalenie wysokości alimentów.

- sprawy o podział majątku po rozwodzie

- sprawy związane z opieką nad dziećmi po rozwodzie, orzekane przez sądy rodzinne:

a. o ustalenie kontaktów z dzieckiem,

b. o zmianę wyroku rozwodowego w części dotyczącej rozstrzygnięcia o władzy rodzicielskiej nad wspólnymi małoletnimi dziećmi rozwiedzionych małżonków,

c. wypracowanie planu opieki rodzicielskiej.

- inne sprawy

a. zakres współpracy rodziny biologicznej z rodziną zastępczą/adopcyjną,

b. konflikty sąsiedzkie,

c. z zakresu prawa karnego - formy zadośćuczynienia,

d. z zakresu postępowania w sprawach nieletnich - forma sprawiedliwości naprawczej,

e. $\mathrm{z}$ zakresu prawa gospodarczego oraz cywilnego $\mathrm{o}^{17}$.

Jak wskazuje powyższa prezentacja metody mediacji, jest to kolejne narzędzie nie tylko interwencji w sytuacji wystąpienia konfliktów w rodzinie, ale również profilaktyki na rzecz przejmowania przez rodzinę odpowiedzialności za swoje sprawy. Takie, choćby tylko jedno, doświadczenie przez rodzinę wsparcia ze strony mediatora przekłada się na wykorzystanie tego doświadczenia w przyszłych sytuacjach, jakie rodzina będzie przeżywała.

\section{Zakończenie}

O potrzebie podejmowania działań prewencyjnych i profilaktycznych w pracy socjalnej mówi się od dłuższego czasu. Działania interwencyjne, choć bez wątpienia potrzebne, są „droższe” zarówno w wymiarze społecznym, jak i finansowym. Nie bez znaczenia jest również poziom zaufania społecznego do służb pomocowych, które są często spostrzegane jako działające na szkodę rodzin i osób potrzebujących. Brak szybkiej reakcji na przeżywane kryzysy, brak wsparcia we wczesnych ich stadiach albo brak działań zapobiegawczych to najczęstsze zarzuty wobec tych służb. Politycy społeczni zgodnie apelują o wzmocnienie działań zapobiegawczych jako bardziej skutecznych, a w konsekwencji również i tańszych. Nasuwa się zatem pytanie: dlaczego w tak nie-

17 K. Wojtanowicz, Mediacje rodzinne jako sposób na rozwiązywanie konfliktów w rodzinie, [w:] Wybrane zagadnienia pedagogiki rodziny, Kraków 2010, s. 275. 
wielkim stopniu wykorzystujemy $\mathrm{w}$ pracy socjalnej metody profilaktyczne? Wymagają one faktycznie w ich wdrażaniu i stosowaniu większego zaangażowania niż te o charakterze interwencyjnym, jednak co do ich efektywności nie trzeba chyba nikogo przekonywać.

\section{Bibliografia}

Dybowska E., Wojtanowicz K., System wspierania i formy pracy z rodziną, Kraków 2013.

Gójska A., Huryn V., Mediacja w rozwiązywaniu konfliktów rodzinnych, Warszawa 2007.

Kantowicz E., Olubiński A. (red.), Działanie społeczne w pracy socjalnej na progu XXI wie$k u$, Toruń 2004.

Marynowicz-Hetka E., Pedagogika społeczna, Warszawa 2005.

Mediacje rodzinne w praktyce. Poradnik, Kraków 2008.

Pilch T., Lepalczyk I. (red.), Pedagogika społeczna - człowiek w zmieniajacym się świecie, Warszawa 2003.

Przeperski J., Praca z rodziną z zastosowaniem metody Konferencja Grupy Rodzinnej, „es.O.es” (2006) nr 2.

Pytka L., Pedagogika resocjalizacyjna, Warszawa 2001.

Wolska-Prylińska D., Projekt socjalny w kształceniu i działaniu społecznym, Katowice 2010. 